\title{
Expression of PD-1/PD-L1 and PD-L2 in peripheral T-cells from non-small cell lung cancer patients
}

\author{
Oscar Arrieta ${ }^{1, *}$, Edgar Montes-Servín ${ }^{1, *}$, Juan-Manuel Hernandez-Martinez ${ }^{1,2, *}$, \\ Andrés F. Cardona ${ }^{3}$, Eibar Casas-Ruiz ${ }^{1}$, José C. Crispín ${ }^{4}$, Daniel Motola ${ }^{5}$, Diana \\ Flores-Estrada ${ }^{1}$ and Lourdes Barrera ${ }^{1}$ \\ ${ }^{1}$ Functional Unit of Thoracic Oncology and Laboratory of Personalized Medicine, Instituto Nacional de Cancerología, Mexico \\ City, Mexico \\ ${ }^{2}$ CONACyT-Instituto Nacional de Cancerología, Mexico City, Mexico \\ ${ }^{3}$ Clinical and Translational Oncology Group, Institute of Oncology, Clínica del Country, Bogotá, Colombia \\ ${ }^{4}$ Department of Immunology and Rheumatology, Instituto Nacional de Ciencias Médicas y Nutrición Salvador Zubirán, Mexico \\ City, Mexico \\ ${ }^{5}$ Centro Oncológico, Hospital Médica Sur, Mexico City, Mexico \\ *These authors have contributed equally to this work \\ Correspondence to: Oscar Arrieta, email: ogar@unam.mx \\ Keywords: immunotherapy; checkpoint inhibitors; lung adenocarcinoma; prognosis; circulating lymphocytes \\ Received: August 06, $2017 \quad$ Accepted: September 03, $2017 \quad$ Published: October 24, 2017 \\ Copyright: Arrieta et al. This is an open-access article distributed under the terms of the Creative Commons Attribution License \\ 3.0 (CC BY 3.0), which permits unrestricted use, distribution, and reproduction in any medium, provided the original author and \\ source are credited.
}

\section{ABSTRACT}

Binding of programmed death-1 (PD-1) with its ligands (PD-L1/2) transmits a co-inhibitory signal in activated $\mathrm{T}$-cells that promotes $\mathrm{T}$-cell exhaustion, leading to tumor immune evasion. The efficacy of antibodies targeting PD-1 and PD-L1 has led to a paradigm shift in lung cancer treatment but the prognostic and predictive value of tumor PD-L1 expression remains controversial. Evaluating PD-1, PD-L1/2 expression in peripheral blood cells may serve as a potential biomarker for prognosis and response to therapy. In this prospective observational study, plasma cytokine levels and PD-1, PD-L1 and PD-L2 expression was evaluated in circulating CD3 ${ }^{+}$, $\mathrm{CD}^{+}{ }^{+} \mathrm{CD} 4^{+}$and $\mathrm{CD}^{+}{ }^{+} \mathrm{CD} 8^{+}$cells from 70 treatment-naïve patients with advanced NSCLC (Stage IIIB and IV) and from 10 healthy donors. The primary objective was to assess OS according to PD-1, PD-L1, PD-L2 expression status on PBMCs and lymphocyte subsets. Our results indicate that the percentage of PD-L1 ${ }^{+} \mathrm{CD} 3^{+}, \mathrm{PD}-\mathrm{L1}{ }^{+} \mathrm{CD} 3^{+} \mathrm{CD} 8^{+} \mathrm{PD}-$ $\mathrm{L2}^{+} \mathrm{PBMCs}, \mathrm{PD}-\mathrm{L2}^{+} \mathrm{CD}^{+}{ }^{+}, \mathrm{PD}-\mathrm{L2}{ }^{+} \mathrm{CD}_{3}+\mathrm{CD}^{+}$cells was higher in patients than in healthy donors. Survival was decreased among patients with a high percentage of either PD-

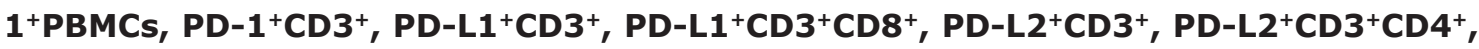
or PD-L2 ${ }^{+} \mathrm{CD}^{+}{ }^{+} \mathrm{CD} 8^{+}$cells. IL-2 and TNF-a showed the strongest association with PDL1 and PD-L2 expression on specific subsets of T-lymphocytes. Our findings suggest that increased PD-1/PD-L1/PDL-2 expression in PBMCs, particularly in T-cells, may be an additional mechanism leading to tumor escape from immune control. This study is registered with ClinicalTrials.gov, number NCT02758314.

\section{INTRODUCTION}

Lung cancer remains the leading cause of cancerrelated deaths in men, and had, in 2015, the second highest absolute incidence globally. It has been estimated that in
2017 lung cancer will account for $13 \%$ of all new cancer cases and for $26 \%$ of cancer-related deaths [1]. NonSmall Cell Lung Cancer (NSCLC) is the predominant type, accounting for approximately $85 \%$ of all newly diagnosed cases, with the majority of patients exhibiting 
advanced-stage disease [2, 3]. It is now widely accepted that the immune system plays a crucial role in preventing or promoting the development and progression of several types of cancer, including lung cancer. Immunotherapy has thus become an important treatment strategy whereby several components of the immune system are targeted to elicit effective anti-tumor responses. Immunotherapeutic approaches to lung cancer have shown great potential to improve treatment outcomes [4].

Transformed cells can evade immune system elimination by decreasing the expression of antigen presentation molecules and co-stimulatory molecules or, by increasing the expression of co-inhibitory molecules [58] such as programmed cell death protein 1 (PD-1). PD-1 is expressed on the surface of activated macrophages, T-lymphocytes, B lymphocytes, NK cells, and on some myeloid cells [9-12], where it inhibits the survival, proliferation and function through its interaction with PD-L1 and L2. The interaction of PD-1 with its ligands attenuates immune responses [13] and protects tumor cells from cytotoxic T-cell attack, leading to immune system evasion [14]. Immune checkpoint inhibitors (ICIs) are antibodies that target co-inhibitory molecules, such as PD-1/PD-L1, to improve anti-tumor immune responses $[15,16]$.

Anti-PD-1 ICIs have achieved higher therapeutic responses than standard-of-care chemotherapy in patients with advanced NSCLC, both in the secondline [17-19] and first-line [20] setting. In these studies, tumor PD-L1 expression was generally associated with higher responses to anti-PD-1 therapy [17, 18, 21-23]. However, a significant number of patients with PD-1/ PD-L1 positive tumors fail to respond to treatment with anti-PD-1 ICIs and a significant number of patients (15$40 \%$ ) with PD-L1 negative tumors benefit from anti-PD-1 ICIs. Consequently, there is still considerable debate with regards to the prognostic and predictive value of tumor PD-L1 expression in stratifying patients eligible for such interventions. Several reports have shown that the expression of PD-1/PD-L1/PD-L2 on the surface of infiltrating T-cells and circulating tumor cells (CTCs) is associated with poor prognosis $[24,25]$. However, the prognostic value of PD-1/PD-L1/PD-L2 expression on peripheral T-cells from NSCLC patients has not been sufficiently evaluated. The aim of this study was to determine whether the expression of PD-1/PD-L1/PD-L2 on PBMCs, particularly on T-cell subsets, was associated with different survival outcomes in NSCLC patients.

\section{RESULTS}

\section{Patient demographics}

Supplementary Table 1 shows that patients $(\mathrm{N}=70)$ and healthy donors $(\mathrm{N}=10)$ exhibited an even distribution with regards to age, gender, diabetes and hypertension.
The only significant difference between groups was with regards to smoking history which was reported by $54.3 \%$ of NSCLC patients. Among NSCLC patients, 32.8\% had an EGFR mutation and $88.6 \%$ presented adenocarcinoma histology. At the time of diagnosis, $14.3 \%$ of patients presented stage IIIB diseases while the remaining $85.7 \%$ had stage IV disease. Brain metastases and pleural effusion was found in $35.7 \%$ and $68.6 \%$ of patients, respectively. Most patients (97.1\%) presented an ECOG of $0-1$. Approximately $93 \%$ of patients received different regimens of chemotherapy: $80 \%$ were treated with Platinum-Taxol; 4.3\% with Pemetrexed; 2.9\% PlatinumGemcitabine; 5.7\% with Platinum-Pemetrexed. Only 7.1\% of patients with EGFR mutations received TKI as firstline treatment. All other patients with EGFR mutations received TKI as a second-line treatment due to delays in obtaining genetic profile results. Patient characteristics are summarized in Supplementary Table 1.

\section{PD-1/PD-L1/PD-L2 expression on T-cells from NSCLC patients}

No differences were found between patients and controls with regards to the percentage of $\mathrm{CD}^{+}, \mathrm{CD}^{+} \mathrm{CD}^{+}$, PD- $1^{+} \mathrm{PBMCs}, \mathrm{PD}-1^{+} \mathrm{CD}^{+}$, PD$1^{+} \mathrm{CD}^{+} \mathrm{CD}^{+}, \mathrm{PD}-1^{+} \mathrm{CD} 3{ }^{+} \mathrm{CD} 8^{+}, \mathrm{PD}-\mathrm{L} 1^{+} \mathrm{CD} 3{ }^{+} \mathrm{CD} 4^{+}$and $\mathrm{PD}-\mathrm{L} 2^{+} \mathrm{CD}^{+}{ }^{+} \mathrm{CD} 8^{+}$cells $(P=0.7813, P=0.6631, P=0.810$, $P=0.9400, P=0.8550, P=7881, P=0.1213$ and $P=0.0812$, respectively).

However, patients had a lower percentage of $\mathrm{CD}^{+}{ }^{+} \mathrm{CD}^{+}$cells than controls $(46.07 \pm 14.62$ vs 61.46 $\pm 6.36 ; P=0.0016)$ as well as a lower percentage of PDL1 ${ }^{+}$PBMCs $(0.77$ [95\% CI $0-4.62$ ] vs 1.1410 [95\% CI $0.71-2.90 ; P=0.0376)$.

In contrast, patients had a higher percentage of PD$\mathrm{L} 1^{+} \mathrm{CD}^{+}$cells $(3.6$ [95\% CI 0.3-8.9] vs 1.535 [95\% CI 0.7375-2.813]; $P=0.0109), \mathrm{PD}-\mathrm{L} 1{ }^{+} \mathrm{CD}^{+}{ }^{+} \mathrm{CD} 8^{+}$cells $(1.5$ [95\% CI 0.08-8.78] vs 0.6978 [95\% CI 0.0562-1.25]; $P=0.0065)$, PD-L2 ${ }^{+}$PBMCs $(0.46$ [95\% CI 0.023-2.08] vs 0.0013 [95\% CI $0-0.4725] ; P<0.0001), \mathrm{PD}_{-\mathrm{L} 2}{ }^{+} \mathrm{CD}^{+}$ cells (0.985 [95\% CI 0.01-4.2] vs 0.01 [95\% CI 0-0.12]; $P<0.0001)$ and $\mathrm{PD}-\mathrm{L}_{2}{ }^{+} \mathrm{CD}^{+} \mathrm{CD}^{+}$cells $(0.5[95 \% \mathrm{CI}$ $0.02-4$ ] vs 0.01 [95\% CI $0-1.34$ ]; $P<0.0001$ ), (Table 1 \& Figure 1).

\section{PD-1/PD-L1 \& PD-L2 expression status (\%) and cytokines levels}

In NSCLC patients, the percentage of $\mathrm{CD}^{+}{ }^{+} \mathrm{PD}-\mathrm{L}^{+}{ }^{+}$, $\mathrm{CD}^{+}{ }^{+} \mathrm{PD}-\mathrm{L} 2{ }^{+}, \mathrm{CD}^{+}{ }^{+} \mathrm{CD} 4^{+} \mathrm{PD}-\mathrm{L}^{+}{ }^{+}$and $\mathrm{CD} 3^{+} \mathrm{CD} 4^{+} \mathrm{PD}-\mathrm{L} 2^{+}$ cells negatively correlated with the levels of IL-2 ( $P=0.019, P=0.044, P=0.009$ and $P=0.036$; respectively). A negative correlation was also found between IL-6 levels and the percentage of $\mathrm{CD} 3^{+} \mathrm{CD} 4^{+} \mathrm{PD}-\mathrm{L} 1^{+}$, $\mathrm{CD}^{+}{ }^{+} \mathrm{PD}-\mathrm{L}_{2}{ }^{+}$and $\mathrm{CD}^{+} \mathrm{CD}^{+} \mathrm{PD}-\mathrm{L} 2^{+}$cells $(P=0.014$, $P=0.010$ and $P=0.017$; respectively). Similarly, the 
Table 1: Percentage of PD-1 / PD-L1 / PD-L2 in immune cells in NSCLC patients and healthy subjects

\begin{tabular}{|c|c|c|c|}
\hline \multirow[t]{2}{*}{ Variable } & $N=10$ & $\mathbf{N}=\mathbf{7 0}$ & \multirow[t]{2}{*}{$P$} \\
\hline & HS & NSCLC & \\
\hline$\%$ of $\mathrm{CD}^{+}$(T-Lymphocytes) & $19.79 \pm 5.79$ & $21.21 \pm 15.92$ & 0.7813 \\
\hline$\% \mathrm{CD}^{+} \mathrm{CD}^{+}$(T-Helper) & $61.46 \pm 6.36$ & $46.07 \pm 14.62$ & 0.0016 \\
\hline$\% \mathrm{CD}^{+} \mathrm{CD}^{+}$(T-Cytotoxic) & $37.67 \pm 6.89$ & $35.76 \pm 13.53$ & 0.6631 \\
\hline \multirow[t]{2}{*}{ Variable } & \multicolumn{2}{|c|}{ PD-1 } & \multirow[t]{2}{*}{$\boldsymbol{P}$} \\
\hline & HS & NSCLC & \\
\hline \multirow[t]{2}{*}{$\%$ of $\mathrm{PBMC}$} & 1.154 & 1.25 & 0.8103 \\
\hline & $(0.8013-2.213)$ & $(0.06-5.580)$ & \\
\hline$\%$ of $\mathrm{CD}^{+}$ & 1.025 & 1.1 & 0.9400 \\
\hline (T-Lymphocytes) & $(0.725-1.45)$ & $(0.11-4.5)$ & \\
\hline$\% \mathrm{CD}^{+} \mathrm{CD}^{+}$ & 0.6113 & 0.6 & 0.8550 \\
\hline (T-Helper) & $(0.2581-0.9688)$ & $(0.013-2.6)$ & \\
\hline$\% \mathrm{CD}^{+} \mathrm{CD}^{+}$ & 0.5645 & 0.565 & 0.7881 \\
\hline (T-Cytotoxic) & $(0.4038-0.7688)$ & $(0-3.6)$ & \\
\hline \multirow[t]{2}{*}{ Variable } & \multicolumn{2}{|c|}{ PD-L1 } & $\boldsymbol{P}$ \\
\hline & HS & NSCLC & \\
\hline \multirow[t]{2}{*}{$\%$ of $\mathrm{PBMC}$} & 1.141 & 0.77 & 0.0376 \\
\hline & $(0.71-2.90)$ & $(0-4.62)$ & \\
\hline$\%$ of $\mathrm{CD}^{+}$ & 1.535 & 3.6 & 0.0109 \\
\hline (T-Lymphocytes) & $(0.7375-2.813)$ & $(0.3-8.9)$ & \\
\hline$\% \mathrm{CD}^{+} \mathrm{CD}^{+}$ & 0.7906 & 1.1 & 0.1213 \\
\hline (T-Helper) & $(0.2475-0.945)$ & $(0.02-8.7)$ & \\
\hline$\% \mathrm{CD}^{+}{ }^{\mathrm{CD}} 8^{+}$ & 0.6978 & 1.5 & 0.0065 \\
\hline (T-Cytotoxic) & $(0.0562-1.25)$ & $(0.08-8.78)$ & \\
\hline \multirow[t]{2}{*}{ Variable } & \multicolumn{2}{|c|}{ PD-L2 } & $\boldsymbol{P}$ \\
\hline & HS & NSCLC & \\
\hline \multirow[t]{2}{*}{$\%(\mathrm{PBMC})$} & 0.0013 & 0.46 & $<0.0001$ \\
\hline & $(0-0.4725)$ & $(0.023-2.08)$ & \\
\hline$\% \mathrm{CD}^{+}$ & 0.01 & 0.985 & $<0.0001$ \\
\hline (T-Lymphocytes) & $(0-0.12)$ & $(0.01-4.2)$ & \\
\hline$\% \mathrm{CD}^{+} \mathrm{CD}^{+}$ & 0.01 & 0.5 & $<0.0001$ \\
\hline (T-Helper) & $(0-1.34)$ & $(0.02-4)$ & \\
\hline$\% \mathrm{CD}^{+} \mathrm{CD}^{+}$ & 0.335 & 0.625 & 0.0812 \\
\hline (T-Cytotoxic) & $(0-1.45)$ & $(0-3.06)$ & \\
\hline
\end{tabular}

$\mathrm{HS}=$ healthy subjects; NSCLC $=$ non-small cell lung cancer, $\mathrm{PBMC}=$ peripheral blood mononuclear cells. 
levels of IL-8 negatively correlated with the percentage of $\mathrm{CD}^{+}{ }^{+} \mathrm{PD}-\mathrm{L} 2^{+}$and $\mathrm{CD}^{+}{ }^{+} \mathrm{CD} 4^{+} \mathrm{PD}-\mathrm{L} 2^{+}$cells $(P=0.044$ and $P=0.017$; respectively). Finally, the plasma concentration of IL-17A negatively correlated with the percentage of $\mathrm{CD}^{+} \mathrm{CD}^{+} \mathrm{PD}-\mathrm{L}^{+}, \mathrm{CD}^{+} \mathrm{CD} 8^{+} \mathrm{PD}-\mathrm{L} 2^{+}$ and $\mathrm{CD}^{+} \mathrm{CD}^{+} \mathrm{PD}-\mathrm{L} 2^{+}$cells $(P=0.008, P=0.018$ and $P=0.025$; respectively). In contrast, there was a positive correlation between the concentration of TNF- $\alpha$
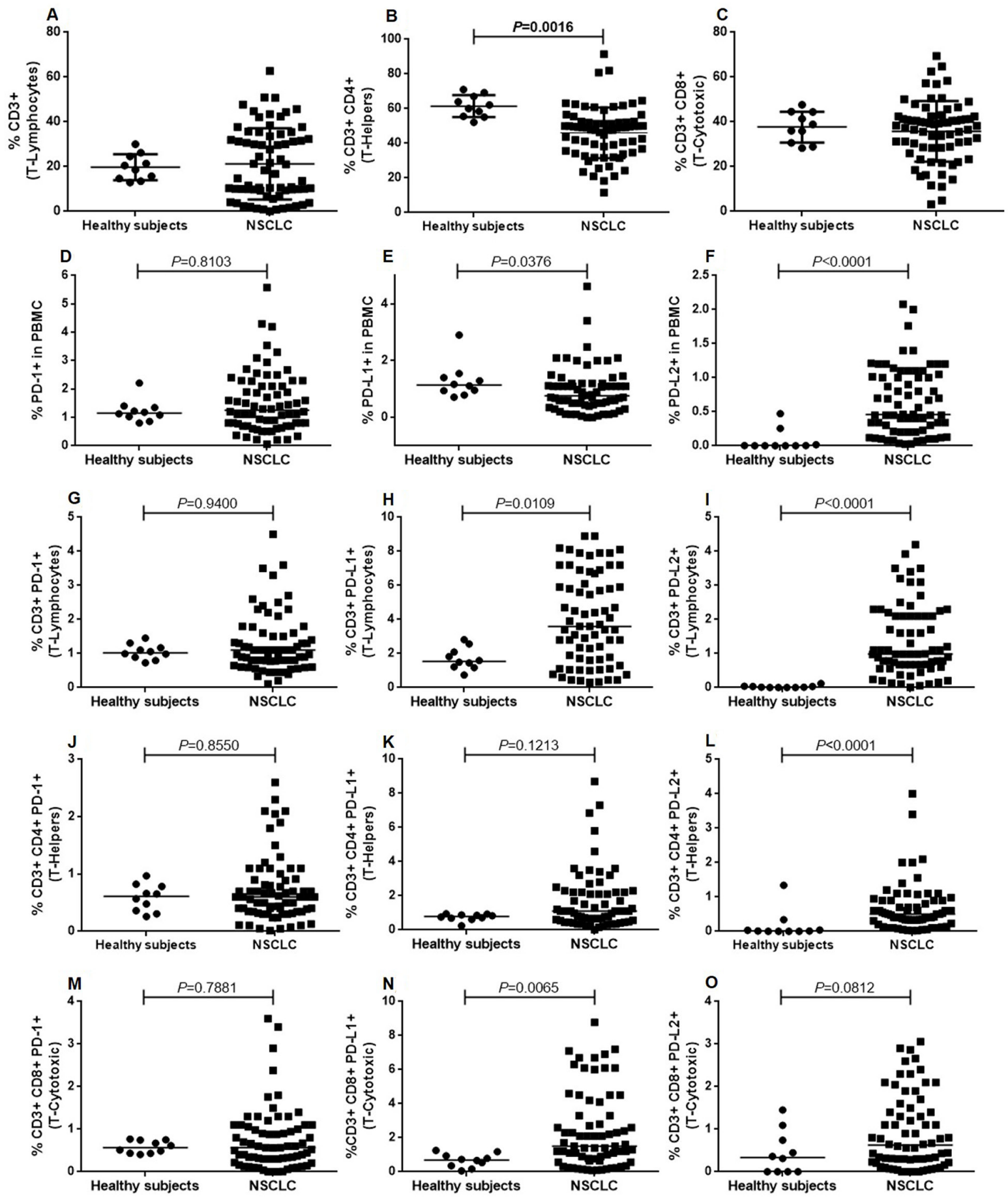

Figure 1: Immune cell subsets in NSCLC patients and healthy subjects. Scatter plot showing the percentage of (A) CD3,$+(B)$ $\mathrm{CD} 3+\mathrm{CD} 4+, \mathbf{C}) \mathrm{CD} 3+\mathrm{CD} 8+$ cells in the PBMC fraction. Panel (D, E) \& (F) show the percentage of PBMCs positive for PD-1, PD-L1 \& PD-L2, respectively. Panel $(\mathbf{G}, \mathbf{H}) \&$ (I) show the percentage of PD-1 +CD3 +, PD-L1 +CD3 +, and PD-L2 +CD3 + cells. Panel (J, K) $\&(\mathbf{L})$ show the percentage of PD-1 +CD3 +CD4 +, PD-L1 +CD3 +CD4 +, and PD-L2 +CD3 +CD4 + cells. Panel (M, N) \& (O) show the percentage of PD-1 +CD3 +CD8 +, PD-L1 +CD3 +CD8 +, and PD-L2 +CD3 +CD8 + cells. 
and the percentage of $\mathrm{CD}^{+} \mathrm{PD}-\mathrm{L1}^{+}, \mathrm{CD} 3^{+} \mathrm{PD}-\mathrm{L} 2^{+}$, $\mathrm{CD}^{+}{ }^{+} \mathrm{CD}_{4}{ }^{+} \mathrm{PD}-\mathrm{L}^{+}, \mathrm{CD}^{+}{ }^{+} \mathrm{CD} 4^{+} \mathrm{PD}-\mathrm{L} 2^{+}, \mathrm{CD}^{+}{ }^{+} \mathrm{CD} 8^{+} \mathrm{PD}-\mathrm{L} 1^{+}$ and $\mathrm{CD}^{+}{ }^{+} \mathrm{CD} 8^{+} \mathrm{PD}-\mathrm{L} 2^{+}$cells $(P=0.003, P=0.003, P=0.032$, $P=0.002, P=0.003$ and $P=0.028$; respectively). Similarly, the concentration of IL-31 positively correlated with the percentage of $\mathrm{CD}^{+} \mathrm{PD}-\mathrm{L} 2^{+}$and $\mathrm{CD}_{3}{ }^{+} \mathrm{CD} 4^{+} \mathrm{PD}-\mathrm{L} 2^{+}$ ( $P=0.02$ and $P=0.046$; respectively), (Supplementary Table 2).

\section{PD-1/PD-L1 \& PD-L2 expression status (\%) and clinical characteristics}

The percentage of $\mathrm{PD}-\mathrm{L}^{+} \mathrm{CD}^{+} \mathrm{CD}^{+}$and $\mathrm{PD}$ $1^{+} \mathrm{CD}^{+} \mathrm{CD}^{+}$cells positively correlated with age $[P=$ 0.028 and $P=0.049$, respectively]. Tobacco exposure was associated with higher percentage of PD- $1^{+}$PBMCs $[P=0.010]$. The percentage of PD- $1^{+}, \mathrm{PD}-\mathrm{L}^{+}{ }^{+}$and PD-L2 ${ }^{+}$ cells was not associated with gender, histology pattern, or clinical stage. EGFR mutation status was associated with a lower percentage of $\mathrm{PD}-\mathrm{L} 2^{+} \mathrm{CD}_{3}{ }^{+}$and $\mathrm{PD}-\mathrm{L} 2^{+} \mathrm{CD} 3^{+} \mathrm{CD} 8^{+}$ $(P=0.051$ and $P=0.008)$. Decline in functional status $($ ECOG $\geq 2)$ was associated with an increase in the percentage of PD- $1^{+} \mathrm{CD}^{+}$cells [95\% CI $0.55-1.63$; $P=$ 0.041], (Table 2).

\section{Clinical factors associated with OS}

The mean follow-up of patients was 22.9 months, with a range of 18.6 to 27.2 months. The median OS was 17.5 months (95\%CI 9.7 - 25.4). Clinical and demographic characteristics (gender, age $>60$, smoking history, histology, EGFR status, metastases, CNS metastases at diagnosis) did not affect median OS when assessed in a multivariate analysis. Patients with an ECOG $\leq 1$ also had a better OS (20.4 vs. 1.84; $P=0.08)$, Supplementary Table 3.

\section{PD-1/PD-L1 \& PD-L2 expression status (\%) and OS}

PD-1 expression on PBMCs and on $\mathrm{CD}^{+}$cells negatively correlated with $\mathrm{OS}(P=0.050 \& P=0.033)$. Patients with $>1.25 \%$ of PD- $1^{+}$PBMCs had an OS of 12.6 months (95\% CI $5.8-19.3)$ vs patients with $\leq 1.25 \%$ of PD-1 $1^{+}$PBMCs, whose OS was 23.3 months (95\% CI 16.330.2). Patients with $>1.1 \%$ of $\mathrm{CD} 3^{+} \mathrm{PD}-1^{+}$had an $\mathrm{OS}$ of 9.9 months $(95 \%$ CI $3.9-15.9)$ vs. patients with $\leq 1.1 \%$ of $\mathrm{CD}^{+} \mathrm{PD}-1^{+}$, whose OS was 23.3 months $(95 \%$ CI $18.7-$ 27.8), (Figure 2A-2B; Supplementary Table 4). There was a significant reduction in the OS of patients with a high percentage of $\mathrm{PD}-\mathrm{L} 1^{+} \mathrm{CD} 3$ and $\mathrm{PD}-\mathrm{L} 1^{+} \mathrm{CD} 8$ cells ( $P=0.012, P=0.006$, respectively). Patients with $>3.6 \%$ of $\mathrm{CD}^{+} \mathrm{PD}-\mathrm{L}^{+}{ }^{+}$or with $>1.5 \%$ of $\mathrm{CD} 3^{+} \mathrm{CD} 8{ }^{+} \mathrm{PD}-\mathrm{L} 1^{+}$cells had an inferior survival rate (6.8 months and 6.9 months) compared with the patients with $\leq$ these cutoff values $(P=0.012)$, (Figure 2C-2D; Supplementary Table 4). No significant associations were found between OS and the percentage of PD-L2 ${ }^{+} \mathrm{PBMCs}$. In contrast, patients with a high percentage of PD-L2 ${ }^{+} \mathrm{CD}^{+}(>0.985 \%)$, $\mathrm{PD}-\mathrm{L}_{2}{ }^{+} \mathrm{CD} 4^{+}$ $(>0.5 \%)$ and $\mathrm{PD}-\mathrm{L} 2{ }^{+} \mathrm{CD} 3^{+} \mathrm{CD} 8^{+}(>0.625 \%)$ cells showed approximately a 15 month decrease in OS $(P=0.011$, $P=0.005, P=0.009$ ), (Figure 2E-2G; Supplementary Table 4).

Calculation of the correlation coefficients for every combination of the predictors selected from the univariate analysis (Supplementary Table 5) revealed a high number of significant correlations, suggesting that collinearity could be a problem for a standard multivariate analysis. Indeed, a collinearity diagnostic test (Supplementary Table 6) yielded tolerances approaching $\cong 0.1$, VIF values $>3$ and eigen values approaching $\cong 0$, all consistent with a high multicollinearity between several of the predictors. Therefore, it was decided to separate each of the predictors into independent multivariate models that included clinical stage and ECOG only. This analysis (Table 3) shows that NSCLC patients are more likely to have reduced OS if they have a high percentage of $\mathrm{PD}-1^{+} \mathrm{CD}^{+} \mathrm{CD} 4^{+}(\mathrm{HR}=$ $1.695 ; P=.025)$, $\mathrm{PD}_{-\mathrm{L} 1}{ }^{+} \mathrm{CD}^{+}(\mathrm{HR}=1.248 ; P<0.0001)$, $\mathrm{PD}-$ $\mathrm{L}^{+} \mathrm{CD}^{+}{ }^{+} \mathrm{CD} 8^{+}(\mathrm{HR}=1.291 ; P<0.0001)$ and $\mathrm{PD}-\mathrm{L}^{+} \mathrm{CD}^{+}$ cells $(\mathrm{HR}=1.370 ; P=0.011)$. In contrast to the univariate analysis, in the multivariate analysis a high percentage of PD $-1^{+} \mathrm{CD}^{+}$, PD- $1^{+} \mathrm{PBMCs}$, PD-L $2{ }^{+} \mathrm{CD}_{3}{ }^{+} \mathrm{CD} 4^{+}$and PD$\mathrm{L}^{+} \mathrm{CD}^{+}{ }^{+} \mathrm{CD} 8^{+}$cells was no longer significantly associated with reduced OS.

\section{DISCUSSION}

The expression of PD-1, PD-L1 \& PD-L2 is modulated by the inflammatory milieu, through the action of cytokines [27]. Our results indicate that levels of several cytokines are strongly associated with the proportion of specific T-cell subsets expressing PD-1, PD-L1 \& PDL2. The pleiotropic nature of cytokine signaling make it difficult to determine the exact relationship between cytokine levels and T-cell expression of PD-1, PD-L1 \& PD-L2. However, it is worth drawing attention to IL-2 and TNF- $\alpha$ since these cytokines showed the highest number of significant correlations. IL-2 negatively correlated with PD-L1 and PD-L2 expression status (\%) in total T-cells (CD3+) and helper T-cells (CD3+CD4+).

It has previously been reported that IL-2 increases PD-L1 expression on human T cells [28], which would be in stark contrast with the negative IL-2 correlation that we found. However, PD-1 activation increases the expression of PTEN while inhibiting the PI3K and Akt pathways [29], which can lead to a decrease in the synthesis and release of IL-2 by T-cells. Indeed, it has been shown that blocking the PD-1/PD-L1 axis increases IL-2 production by T-cells without stimulating their proliferation [30]. Whereas most correlations were negative, TNF- $\alpha$ and IL-31 were the only two cytokines showing a positive association with T-cell subsets. Plasma levels of TNF- $\alpha$ positively 
Table 2: Bivariate analysis of percentage of expression of PD-1 / PD-L1 /PD-L2 and clinical characteristics of NSCLC patients

\begin{tabular}{|c|c|c|c|c|c|c|c|c|c|c|c|c|}
\hline \multirow[t]{2}{*}{ Variable } & \multicolumn{3}{|c|}{$\%$ (PBMC) } & \multicolumn{3}{|c|}{${ }^{\%} \mathrm{CD3}^{+}$(T-Lymphocytes) } & \multicolumn{3}{|c|}{ 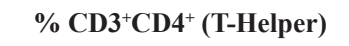 } & \multicolumn{3}{|c|}{${ }^{\%} \mathrm{CD3}^{+} \mathrm{CD8}^{+}$(T-Cytotoxic) } \\
\hline & $\%$ PD-1 & $\begin{array}{c}\% \\
\text { PDL-1 }\end{array}$ & $\begin{array}{c}\% \\
\text { PDL-2 }\end{array}$ & $\%$ PD-1 & $\begin{array}{c}\% \\
\text { PDL-1 }\end{array}$ & $\begin{array}{c}\% \\
\text { PDL-2 }\end{array}$ & $\%$ PD-1 & $\begin{array}{c}\% \\
\text { PDL-1 }\end{array}$ & $\begin{array}{c}\% \\
\text { PDL-2 }\end{array}$ & \% PD-1 & $\begin{array}{c}\% \\
\text { PDL-1 }\end{array}$ & $\begin{array}{c}\% \\
\text { PDL-2 }\end{array}$ \\
\hline \multicolumn{13}{|l|}{ Age } \\
\hline$\leq 60$ & 1.2 & 0.7 & 0.45 & 1.1 & 3.1 & 0.98 & 0.6 & 0.71 & 0.42 & 0.5 & 1.2 & 0.45 \\
\hline$>60$ & 1.3 & 0.78 & 0.46 & 1.1 & 3.6 & 1.1 & 0.6 & 1.3 & 0.6 & 0.6 & 2.1 & 0.78 \\
\hline$P$ & 0.358 & 0.72 & 0.765 & 0.542 & 0.231 & 0.844 & 0.368 & 0.028 & 0.272 & 0.049 & 0.094 & 0.807 \\
\hline \multicolumn{13}{|l|}{ Gender } \\
\hline Female & 1.1 & 0.69 & 0.45 & 1.04 & 3.55 & 0.98 & 0.58 & 1.1 & 0.58 & 0.39 & 1.3 & 0.39 \\
\hline Male & 1.15 & 0.85 & 0.65 & 1.1 & 3.6 & 1.05 & 0.6 & 1.1 & 0.44 & 0.7 & 1.9 & 0.73 \\
\hline$P$ & 0.101 & 0.572 & 0.378 & 0.352 & 0.326 & 0.995 & 0.141 & 0.495 & 0.215 & 0.062 & 0.431 & 0.647 \\
\hline \multicolumn{13}{|l|}{ Smoking } \\
\hline Negative & 1 & 0.67 & 0.4 & 0.98 & 3 & 0.98 & 0.64 & 1.04 & 0.5 & 0.39 & 1.3 & 0.39 \\
\hline Positive & 1.53 & 1.1 & 0.69 & 1.1 & 4 & 1.1 & 0.58 & 1.4 & 0.51 & 0.59 & 1.85 & 0.72 \\
\hline$P$ & 0.01 & 0.069 & 0.118 & 0.402 & 0.185 & 0.505 & 0.363 & 0.135 & 0.781 & 0.201 & 0.319 & 0.457 \\
\hline \multicolumn{13}{|l|}{ Histology } \\
\hline Adenocarcinoma & 1.2 & 0.77 & 0.46 & 1.1 & 3.8 & 0.98 & 0.6 & 1.1 & 0.51 & 0.48 & 1.55 & 0.65 \\
\hline Other & 1.6 & 0.7 & 0.67 & 1 & 2.35 & 1.35 & 0.42 & 0.56 & 0.49 & 0.74 & 1.25 & 0.5 \\
\hline$P$ & 0.712 & 0.684 & 0.839 & 0.796 & 0.245 & 0.705 & 0.465 & 0.096 & 0.719 & 0.093 & 0.512 & 0.314 \\
\hline \multicolumn{13}{|l|}{ EGFR status } \\
\hline Negative & 1.3 & 0.78 & 0.46 & 1.1 & 3.6 & 1.1 & 0.6 & 1.1 & 0.52 & 0.57 & 1.5 & 0.67 \\
\hline Positive & 0.57 & 0.22 & 0.34 & 0.99 & 2.34 & 0.37 & 0.6 & 1.7 & 0.33 & 0.4 & 1.2 & 0.08 \\
\hline$P$ & 0.066 & 0.197 & 0.218 & 0.945 & 0.568 & 0.051 & 0.373 & 0.615 & 0.24 & 0.681 & 0.361 & 0.008 \\
\hline \multicolumn{13}{|l|}{ Clinical Stage } \\
\hline$\leq \mathrm{IIIB}$ & 1.15 & 0.6 & 0.72 & 0.89 & 2.35 & 0.94 & 0.38 & 0.94 & 0.44 & 0.59 & 1.4 & 0.62 \\
\hline IV & 1.25 & 0.79 & 0.46 & 1.1 & 3.8 & 0.99 & 0.61 & 1.1 & 0.51 & 0.52 & 1.65 & 0.63 \\
\hline$P$ & 0.611 & 0.375 & 0.817 & 0.789 & 0.471 & 0.959 & 0.093 & 0.853 & 0.789 & 0.328 & 0.567 & 0.625 \\
\hline \multicolumn{13}{|l|}{ ECOG } \\
\hline 1 & 1.2 & 0.73 & 0.46 & 1.05 & 3.5 & 0.98 & 0.6 & 1.1 & 0.5 & 0.55 & 1.45 & 0.58 \\
\hline$\geq 2$ & 1.89 & 1.62 & 0.74 & 2.2 & 7.47 & 2.25 & 1.65 & 3.45 & 1.27 & 1.63 & 5.59 & 1.75 \\
\hline$P$ & 0.387 & 0.093 & 0.944 & 0.069 & 0.075 & 0.192 & 0.116 & 0.259 & 0.072 & 0.041 & 0.105 & 0.153 \\
\hline \multicolumn{13}{|l|}{ Metastasis } \\
\hline Negative & 1.35 & 0.55 & 0.57 & 1 & 3.4 & 1.9 & 0.42 & 1.45 & 0.6 & 0.6 & 1.45 & 1.4 \\
\hline Positive & 1.2 & 0.79 & 0.46 & 1.1 & 3.8 & 0.98 & 0.61 & 1.1 & 0.46 & 0.45 & 1.55 & 0.56 \\
\hline$P$ & 0.913 & 0.562 & 0.853 & 0.608 & 0.585 & 0.059 & 0.338 & 0.41 & 0.063 & 0.182 & 0.712 & 0.156 \\
\hline \multicolumn{13}{|l|}{ CNS mets } \\
\hline Negative & 1.3 & 0.76 & 0.56 & 0.97 & 3.4 & 0.88 & 0.5 & 1.1 & 0.4 & 0.53 & 1.4 & 0.43 \\
\hline Positive & 1.1 & 0.9 & 0.45 & 1.2 & 5.46 & 1.6 & 0.67 & 1.1 & 0.6 & 0.7 & 2.3 & 0.9 \\
\hline$P$ & 0.893 & 0.48 & 0.215 & 0.193 & 0.141 & 0.015 & 0.206 & 0.672 & 0.015 & 0.492 & 0.19 & 0.033 \\
\hline
\end{tabular}

$\mathrm{HS}=$ healthy subjects, NSCLC $=$ non-small cell lung cancer, $\mathrm{ECOG}=$ Eastern Cooperative Oncology Group, $\mathrm{CNS}$ mets=central nervous system. 
correlated with PD-L1 and PD-L2 expression status (\%) in total T-cells $(\mathrm{CD} 3+)$, helper T-cells (CD3+CD4+) and cytotoxic T-cells (CD3+CD8+). This finding is in agreement with mechanistic studies showing that TNF- $\alpha$ induces PD-L1 expression on the surface of T cells and monocytes $[10,27,31]$. Our results indicate that TNF- $\alpha$ might have a similar effect on PD-L2 expression.

The efficacy of PD-1/PD-L1 ICIs has been demonstrated in numerous preclinical models [29, 32] as well as in several human clinical trials [33-36]. Although PD-1 blockade has dramatically improved the response rate of NSCLC patients, the identification of biomarkers predictive of response has remained elusive. PD-L1 expression in tumors has been evaluated in several studies but its prognostic and predictive value continue to be a matter of debate [37].

It is likely that some of the reliability and reproducibility issues surrounding the use of PD-L1 as a biomarker derive from variable assay methodology, heterogeneity of tumor sampling and surgical inaccessibility [38]. Novel studies have hypothesized that PD-L1 expression in CTCs, found in malignant pleural effusion or in blood from patients with metastatic NSCLC, represents an accurate surrogate for the determination of tumor PD-L1 levels in malignant cells of the primary tumor [24]. However, it has also been suggested that nivolumab may exert its effect on PD-L1 negative patients by a mechanism that is independent of tumoral PD-L1 expression, for example by blocking other inhibitory ligands of the PD-1 receptor such as PD-L2 and thus decreasing the inhibition of T-cells [21].

Our results concur that there are mechanisms independent of tumoral PD-L1 expression by which tumor evasion occurs. Although no differences were found between patients and controls with regards to the percentage of peripheral PBMCs, $\mathrm{CD}^{+}, \mathrm{CD}^{+} \mathrm{CD}^{+}$and $\mathrm{CD}^{+} \mathrm{CD}^{+}$cells, NSCLC patients had a higher percentage of circulating $\mathrm{PD}-\mathrm{L}^{+}{ }^{+} \mathrm{CD} 3{ }^{+}$and $\mathrm{PD}-\mathrm{L}^{+}{ }^{+} \mathrm{CD} 3{ }^{+} \mathrm{CD}^{+}$cells (but not PD- $\mathrm{L}^{+} \mathrm{CD} 3^{+} \mathrm{CD} 4^{+}$), as well as a higher percentage of PD-L2 ${ }^{+}$PBMCs, PD-L2 ${ }^{+} \mathrm{CD}^{+}$and $\mathrm{PD}-\mathrm{L} 2{ }^{+} \mathrm{CD}^{+}{ }^{+} \mathrm{CD}^{+}$ cells (but not $\mathrm{PD}-\mathrm{L} 2^{+} \mathrm{CD}^{+} \mathrm{CD} 8^{+}$).

Furthermore, the survival analysis revealed a dramatic reduction in the OS of patients with a high percentage of PD- $1^{+} \mathrm{PBMCs}, \mathrm{PD}-1^{+} \mathrm{CD}^{+}, \mathrm{PD}-\mathrm{L}^{+} \mathrm{CD}^{+}$, $\mathrm{PD}-\mathrm{L}^{+} \mathrm{CD}^{+}{ }^{+} \mathrm{CD} 8^{+}, \mathrm{PD}-\mathrm{L} 2^{+} \mathrm{CD}^{+}, \mathrm{PD}^{+} 2_{2}{ }^{+} \mathrm{CD}^{+}{ }^{+} \mathrm{CD} 4^{+}$and $\mathrm{PD}-\mathrm{L}_{2}{ }^{+} \mathrm{CD}^{+} \mathrm{CD}^{+}$cells. However, in the multivariate analysis only a high percentage of $\mathrm{PD}-1^{+} \mathrm{CD} 3^{+} \mathrm{CD} 4^{+}$, $\mathrm{PD}-\mathrm{L}^{+} \mathrm{CD}^{+}, \mathrm{PD}-\mathrm{L}^{+}{ }^{+} \mathrm{CD} 3^{+} \mathrm{CD}^{+}$and $\mathrm{PD}-\mathrm{L} 2{ }^{+} \mathrm{CD}^{+}$cells were significantly associated with reduced OS in NSCLC patients. This is likely due to the tight interrelationship governing the expression of receptor and ligands from the same signaling pathway, which causes multicollinearity problems that reduce the power of a multivariate analysis. It is possible that a larger scale study or a different regression model would confirm that, in addition to the predictors previously described, a high percentage of
PD $-1^{+} \mathrm{CD}^{+}$, PD- $1^{+} \mathrm{PBMCs}, \mathrm{PD}-\mathrm{L} 2{ }^{+} \mathrm{CD} 3{ }^{+} \mathrm{CD} 4{ }^{+}$and PD$\mathrm{L} 2^{+} \mathrm{CD}^{+} \mathrm{CD}^{+}$cells would also be associated with reduced OS in NSCLC patients.

Nevertheless, our results indicate that an additional source of PD-1 inhibitory ligands are T-cells themselves. This could represent an additional and important mechanism by which tumor immune evasion occurs in advanced NSCLC patients. However, future studies are necessary to provide a mechanistic insight into how the expression of these proteins leads to tumor immune escape.

This study produced results which corroborate and expand on the findings of previous work in this field. For instance, Zhang et al. reported a significant difference between the mean levels of PD-L1 in the blood serum of advanced NSCLC patients and healthy controls, being $0.723( \pm 0.081) \mathrm{ng} / \mathrm{ml}$ and 0.565 $( \pm 0.048 \mathrm{ng} / \mathrm{ml})$, respectively. By establishing a cut-off point of $0.636 \mathrm{ng} / \mathrm{ml}$, the authors distinguished a clear correlation with survival and found an area under the curve of $0.956(95 \% \mathrm{CI} 0.927-0.985)$ [41]. A more recent study by Meniawy et al. (2016) found that: a) NSCLC patients have a higher percentage of $\mathrm{PD}-\mathrm{L}^{+}{ }^{+} \mathrm{CD}^{+}$and $\mathrm{PD}-\mathrm{L} 1^{+} \mathrm{CD}^{+}{ }^{+} \mathrm{CD} 8^{+}$cells; b) reduced OS is significantly associated (in a univariate analysis) with a high percentage of $\mathrm{PD}-\mathrm{L}^{+}{ }^{+} \mathrm{CD} 3^{+}$and $\mathrm{PD}-\mathrm{L} 1{ }^{+} \mathrm{CD} 3{ }^{+} \mathrm{CD} 8^{+}$cells; c) reduced OS is significantly associated (in a multivariate analysis) with a high percentage of $\mathrm{PD}-\mathrm{L}^{+}{ }^{+} \mathrm{CD} 3^{+}$cells [42]. However, in the current study no differences were found between patients and healthy subjects with regards to the percentage of $\mathrm{PD}-\mathrm{L}^{+}{ }^{+} \mathrm{CD}^{+} \mathrm{CD} 4$ cells, nor were there any associations found between EGFR mutation status and PD-L1 expression. On the other hand, we found that patients with EGFR mutations had a lower percentage of $\mathrm{PD}-\mathrm{L} 2^{+} \mathrm{CD}^{+}$and $\mathrm{PD}-\mathrm{L} 2^{+} \mathrm{CD} 3^{+} \mathrm{CD} 8^{+}$cells, which to the best of our knowledge had not previously been described. Finally, our multivariate analysis revealed that a high percentage of $\mathrm{PD}-1^{+} \mathrm{CD} 3^{+} \mathrm{CD} 4^{+}, \mathrm{PD}-$ $\mathrm{L}^{+}{ }^{+} \mathrm{CD} 3{ }^{+}, \mathrm{PD}-\mathrm{L} 1^{+} \mathrm{CD}^{+}{ }^{+} \mathrm{CD} 8^{+}$and $\mathrm{PD}-\mathrm{L} 2{ }^{+} \mathrm{CD} 3^{+}$cells is significantly associated with reduced OS. These minor discrepancies could be attributed to differences in the baseline characteristics of patients. For instance, whereas our patients were treatment-naïve at the time of sample collection, the majority of patients included in the study by Meniawy et al (2016) had received at least one line of systemic therapy (chemotherapy). Nevertheless, the results from both studies highlight the prognostic value of assessing the expression of PD-1 and its ligands on the surface of peripheral T-cells. In conclusion, it is likely that patients with increased expression of PD-L1 and PDL2 on the surface of T-cells could benefit from PD-1/ PD-L1/PD-L2 blockade even if their tumors are negative for these molecules. This would certainly explain why a significant number of patients with PD-L1 negative tumors have shown responses to anti-PD-1and anti-PD-L1 ICIs $[39,40]$ 

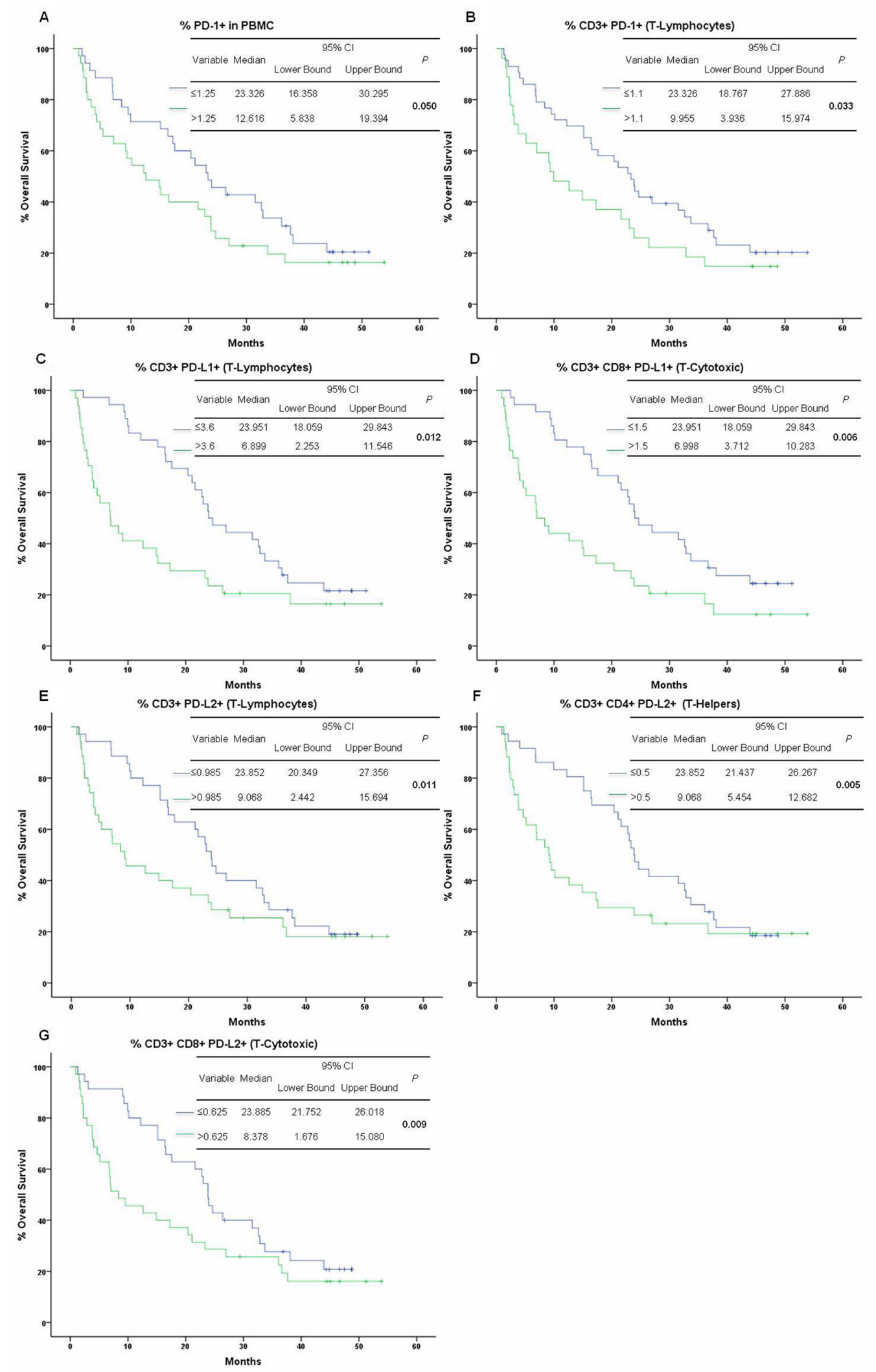

Figure 2: Kaplan-Meier curves of OS by PD-1, PD-L1, PD-L2 expression status. (A) PD-1 cutoff point $\leq 1.25 \%$ in PBMCs and (B) $\leq 1.1 \%$ in CD $3+$ cells; (C) PD-L1 cutoff point $\leq 3.6 \%$ in CD $3+$ cells and (D) $\leq 1.5 \%$ in CD $3+$ CD $8+$ cells; (E) PD-L2 cutoff point $\leq 0.985 \%$ in CD $3+$ cells, $(\mathbf{F}) \leq 0.5 \%$ in CD3 + CD $4+$ cells, and $(\mathbf{G}) \leq 0.625 \%$ in CD $3+$ CD $8+$ cells. 
Table 3: Multivariate analysis for prediction of overall survival in NSCLC patients

\begin{tabular}{|c|c|c|c|c|c|}
\hline \multicolumn{6}{|c|}{ Model 1. ECOG \& clinical Stage } \\
\hline & \multirow[t]{2}{*}{ Variable } & \multirow[t]{2}{*}{ HR } & \multicolumn{2}{|c|}{$95 \%$ Confidence Interval } & \multirow[t]{2}{*}{$\boldsymbol{P}$} \\
\hline & & & Lower Bound & Upper Bound & \\
\hline \multirow[t]{4}{*}{ PD-1 } & $\%$ of PBMC & 1.234 & 0.978 & 1.557 & 0.077 \\
\hline & $\%$ of $\mathrm{CD}^{+}$(T-Lymphocytes) & 1.193 & 0.855 & 1.665 & 0.299 \\
\hline & $\% \mathrm{CD}^{+} \mathrm{CD}^{+}$(T-Helper) & 1.695 & 1.068 & 2.69 & 0.025 \\
\hline & $\% \mathrm{CD}^{+} \mathrm{CD}^{+}$(T-Cytotoxic) & 1.188 & 0.776 & 1.819 & 0.427 \\
\hline \multirow[t]{4}{*}{ PD-L1 } & $\%$ of $\mathrm{PBMC}$ & 1.293 & 0.951 & 1.757 & 0.101 \\
\hline & $\%$ of $\mathrm{CD}^{+}$(T-Lymphocytes) & 1.248 & 1.106 & 1.41 & $<0.0001$ \\
\hline & $\% \mathrm{CD}^{+} \mathrm{CD}^{+}$(T-Helper) & 0.978 & 0.926 & 1.033 & 0.425 \\
\hline & $\% \mathrm{CD}^{+} \mathrm{CD}^{+}$(T-Cytotoxic) & 1.291 & 1.118 & 1.491 & $<0.0001$ \\
\hline \multirow[t]{4}{*}{ PD-L2 } & $\%(\mathrm{PBMC})$ & 1.122 & 0.637 & 1.974 & 0.69 \\
\hline & $\% \mathrm{CD}^{+}$(T-Lymphocytes) & 1.37 & 1.075 & 1.745 & 0.011 \\
\hline & $\% \mathrm{CD}^{+} \mathrm{CD}^{+}$(T-Helper) & 1.009 & 0.721 & 1.411 & 0.96 \\
\hline & $\% \mathrm{CD}^{+} \mathrm{CD}^{+}$(T-Cytotoxic) & 1.342 & 0.988 & 1.823 & 0.06 \\
\hline
\end{tabular}

$\mathrm{HR}=$ hazard ratio, $\mathrm{PBMC}=$ peripheral blood mononuclear cells.

Our data highlight the need for future studies evaluating the efficacy of anti-PD-1 and anti-PD-L1 therapies in patients with differential expression of PDL1 and PD-L2 on peripheral T-lymphocytes. This may represent a potential biomarker to noninvasively predict the therapeutic efficacy of PD-1/PD-L1 blockade in patients

\section{MATERIALS AND METHODS}

\section{Study design}

In this prospective observational study, a total of 70 treatment-naïve patients with advanced NSCLC (stage IIIB \& IV) were recruited from May 2013 to June 2014 at the Lung Cancer Clinic of the "Instituto Nacional de Cancerología" of Mexico (INCan). The inclusion criteria were: Adult patients ( $>18$ years), newly diagnosed, histopathological confirmation of NSCLC, disease stage IIIB or IV, Eastern Cooperative Oncology Group (ECOG) status of 0-2, no history of autoimmune diseases or of recent steroid therapy, without prior treatment (radiation, chemotherapy or immunotherapy) but eligible to receive standard of care chemotherapy (Platinum-Taxol, Pemetrexed, Platinum-Gemcitabine and Platinum Pemetrexed) or TKIs at the time of diagnosis. Clinicopathological characteristics were recorded from patients at the time of diagnosis. Blood samples of healthy subjects $(\mathrm{N}=10)$, paired by age and gender, and with complete information regarding smoking history, woodsmoke exposure and comorbidities, were obtained from the Blood Transfusion Center bank. Written informed consent was obtained from each patient prior to enrolment. This protocol was approved by the Institutional Review Board and Ethics Committee (INCAN [011/018/ICI] $[\mathrm{CB} / 683])$ of the INCan. This study is registered with ClinicalTrials.gov (NCT02758314).

\section{Sample collection}

Blood samples were prospectively collected (pretreatment) and handled as follows: a) Eight milliliters of blood were drawn into a plastic EDTA tube (BD Biosciences; San Jose, Ca, US). Upon collection, the plasma was separated by centrifugation and stored at $-80^{\circ} \mathrm{C}$ for subsequent cytokine analysis; b) Eight milliliters of blood were drawn into $3.2 \%$ citrate tubes (BD Biosciences). Upon collections samples were diluted with PBS (1:1, v:v) and separated by density gradient centrifugation (Lymphoprep; AXIS-SHIELD PoC AS, Norway). The interphase, containing peripheral blood mononuclear cells (PBMCs), was stored in liquid nitrogen for subsequent immunophenotyping.

\section{Immunophenotyping}

Expression of PD-1/PD-L1/PD-L2 was assessed retrospectively in prospectively collected blood samples. The following combination of human monoclonal antibodies were used according to the manufacturers' instructions to identify different immune cell populations $\left(\mathrm{CD}^{+}, \mathrm{CD}^{+}\right.$and $\mathrm{CD}^{+} \mathrm{T}$ lymphocytes): anti-CD3-FITC, 
anti-PD-L1-PE, anti-CD8-APC Cy7, anti-PD-1-PE Cy7, anti-PD-L2-APC and anti-CD4-PerCp (BioLegend; San Diego, CA, US). The PBMC fraction was blocked for 5 minutes with a FAB anti-IgG. Samples were incubated for 45 minutes with the appropriate antibodies $(2.5 \mu \mathrm{l})$ at room temperature and protected from light exposure. After incubation, $2 \mathrm{ml}$ of a 1:1 solution of PBS-Fetal bovine serum (FBS) were added to each sample. Samples were then centrifuged at $1100 \mathrm{rpm}$ for 5 minutes. The supernatant was decanted and cells were fixed in paraformaldehyde (1\%).

Gating strategy were set using fluorescence minus one (FMO) for PD-1 /PD-L1 \&PD-L2. The samples were acquired in a FACS Aria II Flow Cytometer (BD, Biosciences, San José, Cal, USA) and analyzed with FlowJo software 10.1 (Tree Star. Ashland, Or, USA). The leukocyte population was gated based on morphological parameters on a forward vs side scatter (FSC/SSC) plot.

\section{Measurement of cytokines and chemokines}

Plasma levels of 14 cytokines (IL-1 $\beta$, IL-2, IL-4, IL6, IL-8, IL-10, IL-12 p70, IL-17A, IL-27, IL-31, IL-29, and IL-33, TNF- $\alpha$, IFN- $\gamma$ ) were quantified as previously described [26]. Briefly, a Pro-Inflammatory and Th1/ Th2/Th17 cytometric bead array assay kit (BD, San Jose, CA, USA) was used according to the manufacturer's instructions. Events were acquired using a FACS Aria II Flow Cytometer (BD, Biosciences, Mexico) and analyzed with FCAP Array Software V. 3.0 (Soft Flow, Pecs, Hungary).

\section{Statistical analysis}

Continuous data were summarized as arithmetic means with standard deviations (SDs) or medians with ranges according to data distribution. Two group comparisons were tested using Student's t test or MannWhitney U (according to data distribution determined by the Kolmogorov Smirnov test). Nominal data was analyzed using the chi square $\left(\mathrm{X}^{2}\right)$ test. Immune parameters associated with clinical variables were determined by bivariate analysis. Correlations were computed by linear regression and analyzed using the Spearman rank correlation test. The Receiver Operating Characteristic (ROC) method was performed to find the best cut-off point value for PD-1, PD-L1 and PDL2 to be used for the survival analysis. OS curves were estimated by the Kaplan-Meier method while comparisons among groups were analyzed with logrank or Breslow tests. Statistically significant and borderline variables ( $P$ values $\leq 0.1)$ were included in the multivariate analyses. Statistical significance was determined as $P \leq 0.05$ with a two-sided test. All data were analyzed using the SPSS software package version 20 (SPSS, Inc., Chicago, IL, US).

\section{Abbreviations}

EGFR: Epidermal Growth Factor Receptor

HS: Healthy subject(s)

ICIs: Immune checkpoint inhibitor

NSCLC: Non-small cell lung cancer

PD-1: Programmed Death-1 receptor

PD-L1: Programmed Death Ligand-1

PD-L2: Programmed Death Ligand-2

PBMC: Peripheral Blood Mononuclear Cell

TKI: Tyrosine Kinase Inhibitor

Treg: Regulatory T-cell(s)

Th: Helper T-cell(Th)

SD: Standard Deviation

\section{ACKNOWLEDGMENTS}

Diana Flores Estrada for her support in the approval and monitoring of the project as coordinator of protocols of the functional unit of thoracic oncology.

\section{CONFLICTS OF INTEREST}

Dr. Oscar Arrieta received research funding from Bristol-Myers Squibb (Mexico). However, in this study no Bristol-Myers or competitor molecules were tested and data analyses was carried out independently. All other authors declare no conflicts of interest.

\section{FUNDING}

This work was supported by the National Council of Science and Technology of Mexico (CONACYT) [161599 to L.B, 87453 to O.A.].

\section{REFERENCES}

1. Siegel RL, Miller KD, Jemal A. Cancer statistics, 2017. CA Cancer J Clin. 2017; 67: 7-30. https://doi.org/10.3322/ caac. 21387.

2. Herbst RS, Heymach JV, Lippman SM. Lung cancer. N Engl J Med. 2008; 359: 1367-80. https://doi.org/10.1056/ NEJMra0802714.

3. Arrieta O, Guzman-de Alba E, Alba-Lopez LF, AcostaEspinoza A, Alatorre-Alexander J, Alexander-Meza JF, Allende-Perez SR, Alvarado-Aguilar S, Araujo-Navarrete ME, Argote-Greene LM, Aquino-Mendoza CA, AstorgaRamos AM, Austudillo-de la Vega H, et al. [National consensus of diagnosis and treatment of non-small cell lung cancer]. [Article in Spanish]. Rev Invest Clin. 2013; 65: S5-84.

4. Scagliotti GV, Bironzo P, Vansteenkiste JF. Addressing the unmet need in lung cancer: the potential of immunooncology. Cancer Treat Rev. 2015; 41: 465-75. https://doi. org/10.1016/j.ctrv.2015.04.001. 
5. Domagala-Kulawik J. The role of the immune system in non-small cell lung carcinoma and potential for therapeutic intervention. Transl Lung Cancer Res. 2015; 4: 177-90. https://doi.org/10.3978/j.issn.2218-6751.2015.01.11.

6. Domagala-Kulawik J, Osinska I, Hoser G. Mechanisms of immune response regulation in lung cancer. Transl Lung Cancer Res. 2014; 3: 15-22. https://doi.org/10.3978/j. issn.2218-6751.2013.11.03.

7. Aerts JG, Hegmans JP. Tumor-specific cytotoxic T cells are crucial for efficacy of immunomodulatory antibodies in patients with lung cancer. Cancer Res. 2013; 73: 2381-8. https://doi.org/10.1158/0008-5472.CAN-12-3932.

8. Codony-Servat J, Rosell R. Cancer stem cells and immunoresistance: clinical implications and solutions. Transl Lung Cancer Res. 2015; 4: 689-703. https://doi. org/10.3978/j.issn.2218-6751.2015.12.11.

9. Agata Y, Kawasaki A, Nishimura H, Ishida Y, Tsubata T, Yagita H, Honjo T. Expression of the PD-1 antigen on the surface of stimulated mouse $\mathrm{T}$ and $\mathrm{B}$ lymphocytes. Int Immunol. 1996; 8: 765-72.

10. Keir ME, Butte MJ, Freeman GJ, Sharpe AH. PD-1 and its ligands in tolerance and immunity. Annu Rev Immunol. 2008; 26: 677-704. https://doi.org/10.1146/annurev. immunol.26.021607.090331.

11. Basso D, Fogar P, Falconi M, Fadi E, Sperti C, Frasson C, Greco E, Tamburrino D, Teolato S, Moz S, Bozzato D, Pelloso M, Padoan A, et al. Pancreatic tumors and immature immunosuppressive myeloid cells in blood and spleen: role of inhibitory co-stimulatory molecules PDL1 and CTLA4. An in vivo and in vitro study. PLoS One. 2013; 8: e54824. https://doi.org/10.1371/journal.pone.0054824.

12. Chen S, Liu H, Su N, Zhang G, Wang L. Myeloid-derived suppressor cells promote age-related increase of lung cancer growth via B7-H1. Exp Gerontol. 2015; 61: 84-91. https:// doi.org/10.1016/j.exger.2014.12.001.

13. Freeman GJ, Long AJ, Iwai Y, Bourque K, Chernova T, Nishimura H, Fitz LJ, Malenkovich N, Okazaki T, Byrne MC, Horton HF, Fouser L, Carter L, et al. Engagement of the PD-1 immunoinhibitory receptor by a novel B7 family member leads to negative regulation of lymphocyte activation. J Exp Med. 2000; 192: 1027-34. https://doi. org/10.1084/jem.192.7.1027.

14. Dong H, Strome SE, Salomao DR, Tamura H, Hirano F, Flies DB, Roche PC, Lu J, Zhu G, Tamada K, Lennon VA, Celis E, Chen L. Tumor-associated B7-H1 promotes T-cell apoptosis: a potential mechanism of immune evasion. Nat Med. 2002; 8: 793-800. https://doi.org/10.1038/nm730.

15. Karachaliou N, Cao MG, Teixido C, Viteri S, MoralesEspinosa D, Santarpia M, Rosell R. Understanding the function and dysfunction of the immune system in lung cancer: the role of immune checkpoints. Cancer Biol Med. 2015; 12: 79-86. https://doi.org/10.7497/j.issn.2095-3941.2015.0029.

16. Ahmadzadeh M, Johnson LA, Heemskerk B, Wunderlich JR, Dudley ME, White DE, Rosenberg SA. Tumor antigen-specific CD8 $\mathrm{T}$ cells infiltrating the tumor express high levels of PD-1 and are functionally impaired. Blood. 2009; 114: 1537-44. https://doi.org/10.1182/ blood-2008-12-195792.

17. Brahmer J, Reckamp KL, Baas P, Crino L, Eberhardt WE, Poddubskaya E, Antonia S, Pluzanski A, Vokes EE, Holgado E, Waterhouse D, Ready N, Gainor J, et al. Nivolumab versus docetaxel in advanced squamous-cell non-small-cell lung cancer. N Engl J Med. 2015; 373: 12335. https://doi.org/10.1056/NEJMoa1504627.

18. Borghaei H, Paz-Ares L, Horn L, Spigel DR, Steins M, Ready NE, Chow LQ, Vokes EE, Felip E, Holgado E, Barlesi F, Kohlhaufl M, Arrieta O, et al. Nivolumab versus docetaxel in advanced nonsquamous non-small-cell lung cancer. N Engl J Med. 2015; 373: 1627-39. https://doi. org/10.1056/NEJMoa1507643.

19. Herbst RS, Baas P, Kim DW, Felip E, Perez-Gracia JL, Han JY, Molina J, Kim JH, Arvis CD, Ahn MJ, Majem M, Fidler MJ, de Castro G Jr, et al. Pembrolizumab versus docetaxel for previously treated, PD-L1-positive, advanced non-small-cell lung cancer (KEYNOTE-010): a randomised controlled trial. Lancet. 2016; 387: 1540-50. https://doi. org/10.1016/S0140-6736(15)01281-7.

20. Reck M, Rodriguez-Abreu D, Robinson AG, Hui R, Csoszi T, Fulop A, Gottfried M, Peled N, Tafreshi A, Cuffe S, O'Brien M, Rao S, Hotta K, et al. Pembrolizumab versus chemotherapy for PD-L1-positive non-small-cell lung cancer. N Engl J Med. 2016; 375: 1823-33. https://doi. org/10.1056/NEJMoa1606774.

21. Rizvi NA, Mazieres J, Planchard D, Stinchcombe TE, Dy GK, Antonia SJ, Horn L, Lena H, Minenza E, Mennecier B, Otterson GA, Campos LT, Gandara DR, et al. Activity and safety of nivolumab, an anti-PD-1 immune checkpoint inhibitor, for patients with advanced, refractory squamous non-small-cell lung cancer (CheckMate 063): a phase 2, single-arm trial. Lancet Oncol. 2015; 16: 257-65. https:// doi.org/10.1016/S1470-2045(15)70054-9.

22. Gettinger S, Rizvi NA, Chow LQ, Borghaei H, Brahmer J, Ready N, Gerber DE, Shepherd FA, Antonia S, Goldman JW, Juergens RA, Laurie SA, Nathan FE, et al. Nivolumab monotherapy for first-line treatment of advanced non-smallcell lung cancer. J Clin Oncol. 2016; 34: 2980-7. https://doi. org/10.1200/JCO.2016.66.9929.

23. Hellmann MD, Rizvi NA, Goldman JW, Gettinger SN, Borghaei H, Brahmer JR, Ready NE, Gerber DE, Chow LQ, Juergens RA, Shepherd FA, Laurie SA, Geese WJ, et al. Nivolumab plus ipilimumab as first-line treatment for advanced non-small-cell lung cancer (CheckMate 012): results of an open-label, phase 1, multicohort study. Lancet Oncol. 2017; 18: 31-41. https://doi.org/10.1016/ S1470-2045(16)30624-6.

24. Meng X, Huang Z, Teng F, Xing L, Yu J. Predictive biomarkers in PD-1/PD-L1 checkpoint blockade immunotherapy. Cancer Treat Rev. 2015; 41: 868-76. https://doi.org/10.1016/j.ctrv.2015.11.001. 
25. Nicolazzo C, Raimondi C, Mancini M, Caponnetto S, Gradilone A, Gandini O, Mastromartino M, Del Bene G, Prete A, Longo F, Cortesi E, Gazzaniga P. Monitoring PD-L1 positive circulating tumor cells in non-small cell lung cancer patients treated with the PD-1 inhibitor Nivolumab. Sci Rep. 2016; 6: 31726. https://doi.org/10.1038/srep31726.

26. Barrera L, Montes-Servin E, Barrera A, Ramirez-Tirado LA, Salinas-Parra F, Banales-Mendez JL, Sandoval-Rios M, Arrieta O. Cytokine profile determined by data-mining analysis set into clusters of non-small-cell lung cancer patients according to prognosis. Ann Oncol. 2015; 26: 42835. https://doi.org/10.1093/annonc/mdu549.

27. Francisco LM, Sage PT, Sharpe AH. The PD-1 pathway in tolerance and autoimmunity. Immunol Rev. 2010; 236: 21942. https://doi.org/10.1111/j.1600-065X.2010.00923.x.

28. Kinter AL, Godbout EJ, McNally JP, Sereti I, Roby GA, O'Shea MA, Fauci AS. The common gamma-chain cytokines IL-2, IL-7, IL-15, and IL-21 induce the expression of programmed death-1 and its ligands. J Immunol. 2008; 181: 6738-46.

29. Parry RV, Chemnitz JM, Frauwirth KA, Lanfranco AR, Braunstein I, Kobayashi SV, Linsley PS, Thompson CB, Riley JL. CTLA-4 and PD-1 receptors inhibit T-cell activation by distinct mechanisms. Mol Cell Biol. 2005; 25: 9543-53. https://doi.org/10.1128/MCB.25.21.9543-9553.2005.

30. Yamazaki T, Akiba H, Koyanagi A, Azuma M, Yagita $\mathrm{H}$, Okumura K. Blockade of B7-H1 on macrophages suppresses $\mathrm{CD} 4+\mathrm{T}$ cell proliferation by augmenting IFNgamma-induced nitric oxide production. J Immunol. 2005; 175: $1586-92$.

31. Kuang DM, Zhao Q, Peng C, Xu J, Zhang JP, Wu C, Zheng L. Activated monocytes in peritumoral stroma of hepatocellular carcinoma foster immune privilege and disease progression through PD-L1. J Exp Med. 2009; 206: 1327-37. https://doi.org/10.1084/jem.20082173.

32. Topalian SL, Drake CG, Pardoll DM. Targeting the PD-1/ B7-H1(PD-L1) pathway to activate anti-tumor immunity. Curr Opin Immunol. 2012; 24: 207-12. https://doi. org/10.1016/j.coi.2011.12.009.

33. Lipson EJ, Forde PM, Hammers HJ, Emens LA, Taube JM, Topalian SL. Antagonists of PD-1 and PD-L1 in cancer treatment. Semin Oncol. 2015; 42: 587-600. https://doi. org/10.1053/j.seminoncol.2015.05.013.

34. Gulley JL, Rajan A, Spigel DR, Iannotti N, Chandler J, Wong DJ, Leach J, Edenfield WJ, Wang D, Grote HJ, Heydebreck AV, Chin K, Cuillerot JM, et al. Avelumab for patients with previously treated metastatic or recurrent non-small-cell lung cancer (JAVELIN Solid Tumor): dose-expansion cohort of a multicentre, open-label, phase 1b trial. Lancet Oncol. 2017; 18: 599-610. https://doi. org/10.1016/S1470-2045(17)30240-1.
35. Goldberg SB, Gettinger SN, Mahajan A, Chiang AC, Herbst RS, Sznol M, Tsiouris AJ, Cohen J, Vortmeyer A, Jilaveanu L, Yu J, Hegde U, Speaker S, et al. Pembrolizumab for patients with melanoma or non-smallcell lung cancer and untreated brain metastases: early analysis of a non-randomised, open-label, phase 2 trial. Lancet Oncol. 2016; 17: 976-83. https://doi.org/10.1016/ S1470-2045(16)30053-5.

36. Somasundaram A, Burns TF. Pembrolizumab in the treatment of metastatic non-small-cell lung cancer: patient selection and perspectives. Lung Cancer (Auckl). 2017; 8: 1-11. https://doi.org/10.2147/LCTT.S105678.

37. Rimm DL, Han G, Taube JM, Yi ES, Bridge JA, Flieder DB, Homer R, West WW, Wu H, Roden AC, Fujimoto J, $\mathrm{Yu} \mathrm{H}$, Anders R, et al. A prospective, multi-institutional, pathologist-based assessment of 4 immunohistochemistry assays for PD-L1 expression in non-small cell lung cancer. JAMA Oncol. 2017. https://doi.org/10.1001/ jamaoncol.2017.0013.

38. Remon J, Chaput N, Planchard D. Predictive biomarkers for programmed death-1/programmed death ligand immune checkpoint inhibitors in nonsmall cell lung cancer. Curr Opin Oncol. 2016; 28: 122-9. https://doi.org/10.1097/ CCO.037275R1037275R10263.

39. Fehrenbacher L, Spira A, Ballinger M, Kowanetz M, Vansteenkiste J, Mazieres J, Park K, Smith D, ArtalCortes A, Lewanski C, Braiteh F, Waterkamp D, He P, et al. Atezolizumab versus docetaxel for patients with previously treated non-small-cell lung cancer (POPLAR): a multicentre, open-label, phase 2 randomised controlled trial. Lancet. 2016; 387: 1837-46. https://doi.org/10.1016/ S0140-6736(16)00587-0.

40. Barlesi F, Park K, Ciardiello F, von Pawel J, Gadgeel S, Hida T, Kowalski D, Dols MC, Cortinovis D, Leach J, Polikoff J, Gandara D, Barrios CH, et al. Primary analysis from OAK, a randomized phase III study comparing atezolizumab with docetaxel in 2L/3L NSCLC. Ann Oncol. 2016. https://doi.org/10.1093/annonc/mdw435.43.

41. Zhang J, Gao J, Li Y, Nie J, Dai L, Hu W, Chen X, Han J, Ma X, Tian G, Wu D, Shen L, Fang J. Circulating PD-L1 in NSCLC patients and the correlation between the level of PD-L1 expression and the clinical characteristics. Thorac Cancer. 2015; 6: 534-8. https://doi. org/10.1111/1759-7714.12247.

42. Meniawy TM, Lake RA, McDonnell AM, Millward MJ, Nowak AK. PD-L1 on peripheral blood T lymphocytes is prognostic in patients with non-small cell lung cancer (NSCLC) treated with EGFR inhibitors. Lung Cancer. 2016; 93: 9-16. https://doi.org/10.1016/j.lungcan.2015.12.006. 